\title{
Impact of Violence against Children in the Family Related To Law Number 23 Year 2004 Concerning Deletion of Violence in Household
}

\author{
Muhammad Rizal ${ }^{1}$, Fathul Djannah ${ }^{2}$ \\ ${ }^{1}$ State Islamic University of North Sumatra \\ ${ }^{2}$ Panca Budi University, Medan, Indonesia \\ djannahf@gmail.com
}

\begin{abstract}
The aim of the study is to find out the impact of violence against children in the family related. This research is a normative juridical study, the approach of which is a normative legal approach, which examines the rules of law relating to factors that cause violence against children in the household, the impact of violence on children in the household, efforts to protect children victims of violence in the home stairs. The result shows that the Factors that cause violence against children in the household are Psychodynamics models the occurrence of violence is caused by the lack of "mothering / traces of a mother." Someone who has never been cared for or cared for by a mother properly, then she cannot be a mother and care for her own children; Personality or character trait models, almost the same as psychodynamic, parents of children who are not mature enough, too aggressive, frustrated / bad character; Social learning model, lack of social skills, which is shown by feeling dissatisfied because of being a parent, feeling very disturbed by the presence of children, requires children to always behave like adults; Family structure model, which refers to the dynamics between families that have a causal relationship with violence; Environmental stress model, which sees children and women as a multidimensional problem and puts "life pressure" as the main cause.
\end{abstract}

Keywords

Legal satisfaction; Impact of violence; against childrenp; family

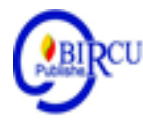

\section{Introduction}

This paper traces Foucault's notion of power in Kate Chopin's the Awakening. It looks at Children are the hope of the nation and when it comes to replacing the older generation in continuing the wheels of the nation's life. They will determine the future welfare of the nation. Children need to be fostered well so that they are not wrong in their lives later. They are expected to be able to carry out activities that can improve their abilities and skills and benefit the community.

Children are also part of the young generation, as one of the human resources, which is the potential and successor to the ideals of the nation's struggle, which has a strategic role and has special characteristics and traits. In maintaining this potential, children need coaching and protection in order to ensure physical, mental, and social growth and development as a whole, in harmony, in harmony, and in balance.

Children are the creation of God Almighty, must be protected and protected with respect, dignity, and self-respect in a reasonable manner both legally, economically, 
politically, socially, and culturally without distinguishing between tribes, religions, races, and groups. Children must be guaranteed the right of life to grow and develop in accordance with the nature and nature.

The family is a place for children to get attention and affection, and protection. family is the smallest society consisting of: father, mother, child, grandfather and grandmother. The family plays an active role in determining the child's development. Children who are created by God Almighty must be protected and protected by fair respect, dignity, and dignity.

Violence often occurs against children and the perpetrators are the family itself, such as violence in the form of sexual harassment in the form of sexual abuse, or rape, child trafficking, murder, beatings. Violence is destructive, dangerous and frightening. The loss of a child as a victim of violence committed by the family is not only material, but also immaterial in the form of emotional and psychological shocks, which can affect his future life.

Child protection has been regulated in legislation and policies, which basically refers to the existence of children in the life of the nation and state. In Law No.4 of 1979 concerning Child Welfare, it is explicitly determined that children have the right to welfare, care, care, and guidance based on affection, both in the family, or in special care to be able to grow and develop properly, both physically, physically, spiritually, as well as socially.

Various kinds of acts of violence committed by adults against children also reflect their lack of understanding of the process of growth and development of these children. The socialization of violence that occurs basically is not born of a vacuum, there are sociocultural conditions that produce and support the survival of such social patterns. The conditions that support the dissemination of violence can at least be categorized into conditions: culture or culture, social conditions and economic conditions. The socialization of violence that occurs at home for example, is supported by cultural values and social conditions that are different from acts of violence that occur in public spaces (public space). A distinction needs to be made on the location of the violence, to be able to determine the conditions of its supporters more closely.

\section{Review of Literature}

\subsection{Factors that Cause Violence Against Children}

Models that can have a relationship with violence are:

1) Psychodinamyc model, the occurrence of violence is caused by the lack of "mothering / traces of a mother." Someone who has never been cared for or cared for by a mother properly, then she cannot be a mother and care for her own children;

2) Personality or character trait models, almost the same as psychodynamic, but in this case do not pay too much attention to what has been experienced by parents as perpetrators of violence, but assume that this is due to parents of children who are not yet mature enough, too aggressive, frustrated / bad character;

3) Social learning model, lack of social skills, which is shown by feeling dissatisfied because of being a parent, feeling very disturbed by the presence of children, requires children to always behave like adults.

4) Family structure model, which refers to the dynamics between families that have a causal relationship with violence.

5) Environmental stress model, which sees children and women as a multidimensional problem and places "depressing life" as the main cause. If there is a change in the 
factors that shape the human environment, such as welfare, low education, lack of work, it will cause violence on children;

6) Social-Psychological models, in this case "frustration" and "stress" are the main factors in causing violence to children. Stress can occur due to various reasons, such as; domestic conflict, social isolation, etc.

7) Mental illness model, violence in children occurs due to neurological disorders, psychiatric illnesses.

\subsection{Forms of Violence against Children}

From some of the events above can be seen that forms of violence experienced by children and women, namely in the form of sexual harassment in the form of sexual abuse, or rape, trafficking or trafficking of children and women, murder, stabbing or beatings. These events are only a small part of the violence that occurred. From these incidents, it is known that the perpetrators of acts of violence against children are not only people who are not known to the victims, but also perpetrators who are known to victims and have blood relations with victims, or in other words the perpetrators are one of the victims' own family members.

Forms of violence against children and women, ranging from neglect to rape and murder, which can be classified in 4 (four) types, namely:

1) Emotional Abuse (emotional violence), can occur if there are parents who know the desire of their children to ask for attention but the parents do not give what their children want but instead ignore it. Children will remember all emotional violence if emotional violence is consistent.

2) Verbal Abuse (violence with words), born as a result of screaming, curses parents towards children, when children ask for something parents do not give instead to yell. When the child invites to talk, the parent does not respond, instead rebukes with a scream, the child will remember all of this verbal violence if all of this verbal violence occurs within a certain period of several months, years.

3) Physical Abuse (physical abuse), this occurs when a child receives a blow from a parent. This type of violence will be remembered by the child especially if the violence leaves a mark on the body of the child, because a scar that remains will always remind the child of the event that caused the injury.

4) Sexual Abuse (sexual violence), this type of violence occurs if there is sexual activity carried out by an adult against a child.

Child abuse occurs in a variety of forms, which can be classified into the following categories:

1) Physical abuse refers to an injury found in a child and a woman not because of an accident but the injury is the result of beatings with objects or multiple repeated attacks.

2) Physical neglect (physical neglect) of this category of violence can be identified generally from the lethargy of a child and woman, paleness and in a state of malnutrition. The child is usually in a dirty / unhealthy condition, inadequate clothing, and inadequate health. But this must also be seen from the socio-economic situation of a family. For example, in a poor family who, despite giving their best to their children, are still seen in the circumstances above, categorized as physical neglect.

\footnotetext{
${ }^{1}$ Pusat Kajian dan Perlindungan Anak, 1995, Kekerasan Terhadap Anak, p. 29-32.
} 
3) Emotional abuse (emotional abuse) and neglect (neglect). Pointing to cases where parents / guardians fail to provide a loving environment for a child to be able to grow, learn, and develop. These failures can be manifested by not caring, discriminating, terrorizing, threatening, or blatantly rejecting children.

4) Sexual abuse (sexual violence). Sexual violence refers to every sexual activity. This form of violence can be in the form of assault or without assault. Including the category of assault if a child suffers physical injury and emotional trauma that is extraordinary. In the category of sexual violence without assault the child does not experience physical injury but still suffers emotional trauma. If an adult has sexual relations with a child under the age of 14 (fourteen) years, then the action is referred to as "statutory rape" and if the child is under the age of 16 (sixteen) years it is referred to as "carnal connection". "Statutory rape" perpetrators will receive a higher sentence than perpetrators of "carnal connections."

\subsection{Impact of Violence on Children}

The impact of parenting patterns on the personality development and behavior of children is as follows. Permissive parenting causes children to be conscientious, self-winning and aggressive. Other consequences such as: opposing, do not want to succumb to adults or parents, low self-confidence, orientation to compete and low achievement, self-control is very lacking, quick to anger, aimless and weak in directing the objectives of their activities, and are mastering hard once. Authoritarian parenting patterns are children being timid, anxious or anxious, moody, unhappy, easily disturbed and irritating, passive hostility and using deception, easily stressed or tense, easily irritated and withdrawn from society, and not directed. Meanwhile, authoritative parenting, causing children to be active or full of enthusiasm and suave. Another impact of authoritative parenting is self-confidence, good control or introspective, cheerful or fun, able to get along well with peers, able to cope with stress or pressure well, have attention and curiosity in romance stories, can work well together with adults, obedient or easily regulated, has specific goals, and is achievement oriented. In addition, children will always think rationally and have a healthy competition spirit.

\section{Research Method}

This research is a normative juridical study, the approach of which is a normative legal approach, which examines the rules of law relating to factors that cause violence against children in the household, the impact of violence on children in the household, efforts to protect children victims of violence in the home stairs. Based on the characteristics of the problem formulation in this study, the type of research is classified as descriptive analysis, which is a method carried out through assessment and analysis by providing a general and overall picture of the factors that cause violence against children in the household, the impact of violence on children in the household, efforts to prevent violence against children in the household. More specifically the method used in this study is the normative legal research method (normative juridical).

The data collection method in this study was adopted by Library Research, namely the method of library study obtained principles, conceptions, views, legal doctrines as well as the contents of the legal norms obtained from two main references namely general (legislation, regulations, textbooks, dictionaries) and special (journals, research reports, etc.). The data 
used in this study are related to the factors that cause violence against children in the household, the impact of violence on children in the household, efforts to prevent violence against children in the household

\section{Discussion}

\subsection{Legal Protection of Children}

According to J.T. Simorangkir, the law is a forceful regulation that determines human behavior in the community that is made by official bodies. This legal definition is important to know the nature and purpose of the law itself. The purpose of the law itself is to obtain truth and justice. According to Van Apeldoorm the purpose of the law is to regulate the association of other people's lives in peace. Arif Gosita said that the child protection law is a (written) law that guarantees that children actually carry out their rights and obligations. Bismar Siregar said that the legal aspect of protection was more focused on children's rights that are regulated in the law and not the obligation, bearing in mind (juridical) the child has not been burdened with obligations. follows:

Some formulations regarding child protection law according to Arif Gosita are as

1. Child protection law is a human problem which is a social reality. When viewed according to dimensionally correct proportions, the child protection law has a mental, physical and social (legal) perspective. This means, their understanding and application are integrative.

2. Child protection law is an interaction between certain parties, due to an interrelation between existing phenomena and mutual influence. It needs to be researched, understood and lived which is involved in the existence of the child protection law. Also examined, understood, and lived symptoms that affect the law of child protection (including individuals and social institutions). Child protection law is a difficult and complicated problem.

3. Child protection law is an individual action that is influenced by certain social elements or certain community, such as: interests (can be motivated), social institutions (family, school, pesantren, government and so on). Understand and appreciate precisely the causes of people making child protection laws as an individual act (alone or together) understood these social elements.

4. Child protection law can lead to legal problems (juridical) which have legal consequences, which must be resolved based on and based on the law.

5. Child protection laws cannot protect children, because the law is only a tool or means used as a basis or guideline for people to protect children. So what is important here is the legislators relating to child protection. It is often taught or interpreted wrongly, that the law can protect people. That thinking makes people mistake the law as always right, it can't be corrected, and so on.

6. Child protection law exists in various laws, because the interests of children are in various fields of the family, nation and state society. ${ }^{2}$

Over the past five years Indonesia has moved swiftly in its efforts to put human rights into law. So one of the most important steps he took was to adopt the Child Protection Act.

\footnotetext{
${ }^{2}$ Era Hukum Jurnal Ilmiah Hukum No. 4/ Th V/April 1999, Perlindungan Hukum Terhadap Korban Kejahatan Perdagangan Anak, Fakultas Hukum Taruma Negara, Jakarta, 1999, p. 274-275
} 
This new law is a powerful tool in implementing the Convention on the Rights of the Child (CRC) in Indonesia. In it regulates the basic rights of children to obtain identity, freedom, education, health services, entertainment and protection. This law is the main framework and is very useful in terms of providing protection to the most vulnerable children, including children who are still economically and sexually exploited, children who are trafficked, children who have problems with the law, children who are victims of violence and abuse, children who are in conflict situations, children from minority and isolated groups, children who are neglected or children who are neglected and disabled.

The drafting of Law No. 23 of 2002 concerning Child Protection was motivated by the ratification of the Convention on the Rights of the Child by Indonesia in 1990 after the convention was adopted by the UN General Assembly to regulate the issue of the special rights and needs of children.

Article 1 Item 1 of intervention Law No. 23 of 2002 concerning Protection of children, mentioning a child is someone who is not yet 18 (eighteen) years old, including children who are still in the womb. This article has a very broad scope. The law must be implemented and enforced. Everyone expects the application of the law in the event of a concrete event. In enforcing the law there are 3 (three) elements which must always be considered, namely: legal certainty (Rechtssicherheit), expediency (Zweckmassigkeit) and justice (Gerechtigheit). How is the law that must apply. This is needed to achieve legal certainty.

Sudikno Mertokusumo assessed that legal certainty is a justifiable protection against arbitrary actions, which means that a person will be able to obtain something that is expected under certain circumstances. ${ }^{3}$ The certainty of law which is the hope of the community becomes very important in the law itself. This is because at the same time whatever the contents of the articles contained in a legal regulation, it does not mean anything if it can not provide legal certainty in its implementation.

In law enforcement there must be a compromise between the three elements. These three elements must receive proportionally balanced attention. But in practice it is not always easy to work out a proportionally balanced compromise between the three elements.

Legal protection for children can also be seen in Law No. 23 of 2002 concerning Child Protection is as follows:

a. Article 59 of Law No. 23 of 2002 determines:

The government and other institutions are obliged and and are responsible for providing special protection to children in emergency situations, children in conflict with the law, children from minority and isolated groups, children who are economically and / or sexually exploited, children who are trafficked, children who are victims of abuse narcotics, alcohol, psychoropic, and other addictive substances (drugs), children of abductees, sales and trafficking, children of victims of mistreatment and neglect.

Article 64 of Law No. 23 of 2002 determines:

Special protection for children in conflict with the law referred to in Article 59 includes children who are in conflict with the law and children who are victims of criminal acts, are the obligations and responsibilities of the government and the community. (paragraph 1)

Special protection for children who are dealing with the law referred to in paragraph (1) is carried out through:

1) Humane treatment according to the dignity and rights of children;

2) Provision of special assistance for children from an early age;

${ }^{3}$ Sudikno Mertokusumo, Mengenal Hukum, Liberty, Yogyakarta, 1988, p. 134 
3) special facilities and infrastructure for imposing sanctions that are appropriate for the best interests of the child;

4) Imposition of appropriate sanctions for the best interests of the child;

5) Continuous monitoring and recording of the development of children in conflict with the law;

6) Providing guarantees for dealing with parents or family.

7) Protection from giving identity through mass media and to avoid labeling. (paragraph 2 Special protection for children who become victims of criminal acts as referred to in paragraph (1) is implemented through;

1) rehabilitation efforts, both within the institution and outside the institution;

2) efforts to protect from preaching identity through mass media and to avoid labeling.

3) Provision of safety guarantees for victim witnesses and expert witnesses, both physical, mental and social.

4) Providing accessibility to get information about case developments. (paragraph 3).

b. Article 66 of Law No. 23 of 2002 determines

Special protection for children who are exploited economically and / or sexually as meant in Article 59 is an obligation and responsibility of the government and society. Special protection for exploited children as referred to in paragraph (1) is carried out through:

1) Dissemination and / or dissemination of statutory provisions relating to the protection of children who are exploited economically and / or sexually;

2) Monitoring, reporting, and giving sanctions; and

3) Involvement of various government agencies, companies, trade unions, nongovernmental organizations, and the community in the elimination of economic and / or sexual exploitation of children

That domestic violence often occurs, the victims are children. Among these are physical violence, sexual violence, psychological violence, economic violence. In this case the law, especially Law No. 23 of 2004 provides special protection for child victims of domestic violence, among others, as follows:

a. Article 15 of Law No. 23 of 2004 determine:

Every person who hears, sees, or knows about the occurrence of violence in the home must make efforts in accordance with the limits of his ability to:

a. Prevent criminal offenses

b. Provide protection to victims

c. Provide emergency assistance, and

d. Assist in the process of submitting application for protection determination.

Article 16 of Law No. 23 of 2004 determines

1) Within $1 \times 24$ (one time twenty-four) hours from knowing or receiving reports of violence in the household, the police must immediately provide temporary protection to the victim.

2) Temporary protection as referred to in paragraph (1) is given no later than 7 (seven) days after the victim is received or handled.

3) Within 1x24 (one time twenty-four) hours counted from the provision of protection as referred to in paragraph (1), the police must request a letter to determine the protection order from the court. 
a. Article 18 of Law No. 23 of 2004 determine:

The police are required to provide information to victims about the right of victims to receive services and assistance.

b. Article 19 of Law No.23 of 2004 stipulates:

The police must immediately investigate after receiving or receiving reports of domestic violence.

In terms of providing protection and services, lawyers must:

a. Providing legal consultation which includes information on victims' rights and the judicial process.

b. Accompanying victims at the level of investigation, prosecution, and examination in court sessions and assisting victims to fully describe the domestic violence they experienced; or

c. Coordinate with fellow law enforcers, volunteer assistants, and social workers so that the judicial process runs as it should.

d. Article 26 of Law No. 23 of 2004 determine:

1) The victim has the right to report domestic violence directly to the police both at the victim's place and at the crime scene.

2) the victim can give power to the family or others to report domestic violence to the police both at the victim's place and at the scene of the case.

e. Article 27 of Law No. 23 of 2004 determine:

In case the victim is a child, the report can be carried out by the parents, guardians, caregivers, or the child concerned which is carried out in accordance with the provisions of the legislation in force.

f. Article 44 of Law No. 23 of 2004 determine:

1) Every person who commits an act of physical violence within the scope of the household as referred to in article 5 letter a is sentenced to a maximum imprisonment of 5 (five) years or a maximum fine of Rp. 15,000,000.00 (fifteen million rupiah).

2) In the case of acts as referred to in paragraph (1) resulting in the victim getting sick or seriously injured, shall be sentenced to a maximum imprisonment of 10 (ten) years or a

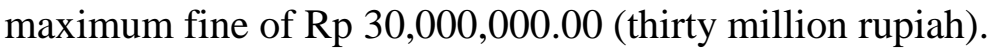

3 ) In the case of the acts referred to in paragraph (2) resulting in the death of the victim, shall be sentenced to a maximum imprisonment of 15 (fifteen) years or a maximum fine of Rp 45,000,000.00 (forty-five million rupiah).

g. Article 45 of Law No. 23 of 2004 determine:

Every person who commits an act of psychological violence within the scope of the household as referred to in Article 5 letter $b$ shall be liable to a maximum imprisonment of 3 (three) years or a maximum fine of $\mathrm{Rp} 9,000,000.00$ (nine million rupiah).

h. Article 46 of Law No. 23 of 2004 determine:

Every person who commits sexual acts as referred to in Article 8 letter a shall be sentenced to a maximum imprisonment of 12 (twelve) years and / or a maximum fine of Rp $36,000,000.00$.

\subsection{Handling Children as Victims of Violence}

Until the 1996s cases of violence against women and children, which were called domestic violence, were increasingly sexually surfacing and shocking the community. On the one hand all condemned and requested that there be strict action against the perpetrators, but on the other hand all parties were also not taboo as to what to do and who should be 
responsible, the handling of cases was not focused and eventually disappeared from the public's attention.

The main concern is the protection of women and children who are victims of domestic violence as it is known that if women and children who are victims of violence want to get justice, they can actually become victims many times, that is when they are in contact with those who should help them whether it is a house sick, police or other parties. This caused many victims to choose to remain silent, so the dark number was very high.

A woman and child victim of domestic violence who decides to seek help is basically biased to contact the hospital, police or other aid agencies. There was a lot of criticism from the public about the abuse done to women and children who were victims of violence when reporting, being examined as a victim's witness to the trial in court.

Women's rights, which are also human rights, have become increasingly in the spotlight of the world so that if law enforcement officials are not immediately introspective and reflect their shortcomings, public criticism will continue to reduce their image. ${ }^{4}$

Speaking of protection, especially in cases of domestic violence (KDRT) both against women and new children reflected and realized in various fields of community life, among others in the field of law, legal certainty must be sought so that various laws have governed a lot especially the rights of children very much considered, because children are a very important part in the ongoing context of a nation that is very vulnerable to various violations of Human Rights (human rights) that can inhibit its growth

\section{Conclusion}

Factors that cause violence against children in the household are Psychodynamics models the occurrence of violence is caused by the lack of "mothering / traces of a mother." Someone who has never been cared for or cared for by a mother properly, then she cannot be a mother and care for her own children; Personality or character trait models, almost the same as psychodynamic, parents of children who are not mature enough, too aggressive, frustrated / bad character; Social learning model, lack of social skills, which is shown by feeling dissatisfied because of being a parent, feeling very disturbed by the presence of children, requires children to always behave like adults; Family structure model, which refers to the dynamics between families that have a causal relationship with violence; Environmental stress model, which sees children and women as a multidimensional problem and puts "life pressure" as the main cause. If there are changes in the factors that shape the human environment, such as welfare, low education, lack of work, it will cause violence on children; Social-psychological models, in this case "frustration" and "stress" are the main factors in causing violence to children. Stress can occur due to various reasons, such as; domestic conflict, social isolation, etc. Mental illness model, violence in children occurs due to neurological disorders, psychiatric diseases.

The impact of violence on children in the family is hampering the growth and development of children both psychologically, physically and socially. Children will remember all emotional violence if emotional violence is consistent. Verbal Abuse (violence with words), born as a result of screaming, curses parents toward children, when children ask for something parents do not give instead to yell. When the child invites to talk, the parent

\footnotetext{
${ }^{4}$ Achie Sudiarti Luhulina, Pemahaman Bentuk-bentuk Tindak Kekerasan Terhadap Perempuan dan Alternatif Pemecahannya, Alumni, Jakarta, 2000, p. 175-176.
} 
does not respond, instead he rebukes with a shout, the child will remember all of this verbal violence if all of this verbal violence occurs within a certain period of several months, years; Physical Abuse (physical abuse), this occurs when a child receives a blow from a parent. This type of violence will be remembered by the child especially if the violence leaves a mark on the body of the child, because a scar that remains will always remind the child of the event that caused the injury; Sexual Abuse (sexual violence), this type of violence occurs if there is sexual activity carried out by an adult against a child.

Special protection in cases of domestic violence (KDRT) both against women and new children is reflected and realized in various fields of community life, including in the field of law, legal certainty must be endeavored so that various legislation regulates many, especially children's rights, which are highly considered, because children are a very important part in the ongoing context of a nation that is very vulnerable to various violations of Human Rights (human rights) that can inhibit its growth. Joint responsibility for the protection of women and children victims of domestic violence, both government officials and the community, including the Indonesian National Police who carry out tasks in the field of law enforcement, protection and service to the community in order to ensure orderliness and upholding of the law and the establishment of public peace in order to realize security and order community, but the togas will not be helpless and effective if the community does not participate.

\section{References}

Abdurrahman dan Riduan Syahrani, (1978). Hukum dan Keadilan, Alumni, Bandung.

A. Hamzah dan Siti Rahayu, (1983). Suatu Tinjauan Ringkas Sistem Pemidanaan di Indonesia, Akademi Pressindo, Jakarta.

A. Gunawan Setiardja, (1993). Hak-hak Asasi Manusia Berdasarkan Ideologi Pancasila. Kanisius, Yogyakarta.

Agung Wahyono dan Siti Rahayu, (1993). Tinjauan Tentang Peradilan Anak di Indonesia. Sinar Grafika, Jakarta.

Arif Gosita, (1989). Masalah Perlindungan Anak, Akademi Pressindo, Jakarta.

Artidjo Alkostar, (1997). Identitas Hukum Nasiona, Fakultas Hukum U.I.I., Yogyakarta.

A. Syamsudin Meliala dan E. Sumaryono. (1985), Kejahatan Anak Suatu Tinjauan dari Psikologi dan Hukum, Liberty, Yogyakarta:

Atmasasmita, Romli, (1997), Peradilan Anak di Indonesia, Penerbit Mandar Maju, Bandung.

Atmadja, I Dewa Gede. Penafsiran Konstitusi Dalam Rangka Sosialisasi Hukum Sisi Pelaksanaan UUD 1945 Secara Murni dan Konsekuen, Pidato Pengenalan Guru Besar Ilmu Hukum Tata Negara pada Fakultas Hukum UNUD, Denpasar, Tahun 1996.

Bachsan Mustafa, (1985). Sistem Hukum Indonesia, Remaja Karya, Bandung.

Bambang Sunggono, (1994). Hukum dan Kebijaksanaan Publik, Sinar Grafika, Jakarta. , (2002). Metode Penelitian Hukum. Raja Grafindo Persada, Jakarta.

Barda Nawawi Arief. (1998). Beberapa Aspek Kebijakan Penegakan dan Pengembangan Hukum Pidana. Penerbit Citra Aditya Bakti, Bandung.

(2001). Masalah Penegakan Hukum dan Kebijakan Penanggulangan Kejahatan. Penerbit Citra Aditya Bakti, Bandung.

,(2002), Perbandingan Hukum Pidana. Penerbit Raja Grafindo Persada, Jakarta.

(1996). Bunga Rampai Kebijakan Hukum Pidana. Citra Aditya Bakti,

Bandung. 
Didi Atmadilaga, (1977). Asas Teknik Penyusunan Usulan Proyek dan Karya Ilmiah (Skripsi, Tesis, Disertasi) Perguruan Tinggi Angkasa, Margahayu, Bandung.

Erna Sofyan Sjukrie, (1998). Perlindungan Hak-Hak Anak yang Melakukan Pelanggaran Hukum, Penerbit PKPM Unika Atma Jaya, Jakarta.

Hamzah, Andi, (1999), Bunga Rampai Hukum Pidana dan Acara Pidana, Penerbit Ghalia Indonesia, Jakarta.

Irwanto. (1997), Perlindungan Anak Prinsip dan Persoalan Mendasar. Makalah. Medan: Seminar Kondisi dan Penanggulangan Anak Jermal, 1 September 1997, MedanSumatera Utara.

Maulana Hassan Wadong, (2000), Advokasi dan Hukum Perlindungan Anak, Penerbit Gramedia Wira Sarana Indonesia, Jakarta.

Muhammad Joni dan Zulchaina Z. Tanamas, (1998), Aspek Hukum Perlindungan Anak Dalam Prespektif Konvensi Hak Anak, Penerbit PT. Citra Aditya Bakti, Bandung.

Padmo Wahjono. (1983). Indonesia Negara Berdasarkan Atas Hukum, Ghalia Indonesia, Jakarta.

Philipus M. Hadjon, (1987), Perlindungan Hukum Bagi Rakyat di Indonesia (Disertasi), Bina Ilmu, Surabaya.

R. Achmad S. Soemadipradja dan Romli Atmasasmita. (1979), Sistem Pemasyarakatan di Indonesia, BPHN Departemen Kehakiman-Bina Ciupta, Jakarta.

Romli Atmasasmita. (1971).Dari Pemenjaraan ke Pembinaan Narapidana. Alumni, Bandung.

R. Soesilo. (1983). KUHP Serta Komentar-komentarnya Lengkap Pasal Demi Pasal. Politeia, Bogor.

Sahardjo. (1963). Pohon Beringin Pengayoman, Rumah Pengayoman Sukamiskin. Bandung.

Satjipto Rahardjo, (2002). Sosiologi Hukum: Perkembangan, Metode dan Pilihan Masalah, Universitas Muhamadiyah Surakarta.

Sanusi Has. (1973). Pengantar Penologi. (Ilmu Pengetahuan Tentang Pemasyarakatan), Monora, Medan.

Soemitro, Irma Setyawati, (1990). Aspek Hukum Perlindungan Anak, Penerbit Bumi Aksara, Jakarta.

Soerjono Soekanto, (1990). Ringkasan Metodologi Penelitian Hukum Empiris, Ind-Hill. Co, Jakarta.

Soekito, Wiratmo Sriwidyowati, (1989). Anak dan Wanita dalam Hukum, Penerbit LP3ES, Jakarta.

Sri edi swasono. (1990). Hak Politik Vs Hak Hukum Dalam Proses Prembangunan, Kopkar Dekopin, Jakarta.

B. Peraturan Perundang-Undangan

Republik Indonesia, Undang-Undang Dasar 1945

, Undang-Undang No. 12 tahun 1995 tentang Pemasyarakatan, Jakarta

, Undang-Undang No. 3 Tahun 1997 tentang Pengadilan Anak, Jakarta.

, Undang-Undang No. 23 Tahun 2002 tentang Perlindungan Anak, Jakarta. , Undang-Undang No. 24 Tahun 2003 tentang Penghapusan Kekerasan Dalam Rumah Tangga.

, Keputusan Presiden No. 36 Tahun 1990 tentang Konvensi Hak Anak, Jakarta.

, Keputusan Presiden No. 88 Tahun 2002 tentang Rencana Aksi Nasional Penghapusan Perdagangan (Trafickking), Jakarta. 